\title{
GPR180 wt Allele
}

National Cancer Institute

\section{Source}

National Cancer Institute. GPR180 wt Allele. NCI Thesaurus. Code C153054.

Human GPR180 wild-type allele is located in the vicinity of $13 q 32.1$ and is approximately $33 \mathrm{~kb}$ in length. This allele, which encodes integral membrane protein GPR180, may play a role in vascular remodeling and receptor signaling. 